НАУКОВИЙ ВІСНИК

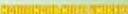

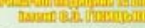

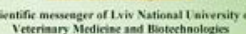

$\rightarrow$

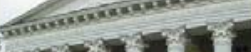

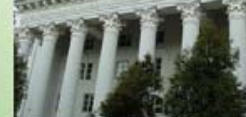
Toм 21 Ni 90

2019
Науковий вісник Дьвівського національного університету ветеринарної медицини та біотехнологій імені С.3. Гжицького. Серія: Сільськогосподарські науки

Scientific Messenger of Lviv National University of Veterinary Medicine and Biotechnologies.

Series: Agricultural sciences
ISSN 2519-2698 print

https://nvlvet.com.ua/index.php/agriculture

UDC [639.3.043.13:636.087.73]:597-111.1.05

\title{
Functional state of an organism of freshwater fish under the influence of abiotic factors
}

\author{
O.V. Honcharova ${ }^{1}$, R.P. Paranjak ${ }^{2}$, B.V. Gutyj ${ }^{2}$ \\ ${ }^{1}$ Dnipro State Agrarian Economic University, Dnipro, Ukraine \\ ${ }^{2}$ Stepan Gzhytskyi National University of Veterinary Medicine and Biotechnologies Lviv, Ukraine
}

Article info

Received 15.02.2019

Received in revised form 15.03.2019

Accepted 18.03.2019

Dnipro State Agrarian and Economic University, Serhii Efremov Str., 25, Dnipro, 49600, Ukraine.

Tel.: +38-095-773-54-88

E-mail: anelsatori@gmail.com

Stepan Gzhytskyi National University of Veterinary Medicine and Biotechnologies Lviv,

Pekarska Str., 50, Lviv,

79010, Ukraine.

E-mail: paranyak_roman@ukr.net
Honcharova, O.V., Paranjak, R.P., \& Gutyj, B.V. (2019). Functional state of an organism of freshwater fish under the influence of abiotic factors. Scientific Messenger of Lviv National University of Veterinary Medicine and Biotechnologies. Series: Agricultural sciences, 21(90), 8287. doi: $10.32718 /$ nvlvet-a9014

The purpose of the work was to conduct a scientific and experimental analysis of the study of the functional state of the organism of hydrobionts while growing in recirculation of aquaculture systems using an unconventional method of water treatment, which was used in the formation of feed forage for their feeding. The experimental part of the work was carried out on the basis of the laboratory of aquatic bioresources and aquaculture of the Biotechnology Faculty of the Dnipro State Agrarian and Economic University and the Scientific and Experimental Center "Aquatic Biodiversity and Aquaculture of the Pre Dnieper" of the Dniprovsky State Agrarian and Economic University. The practical part of the work consisted of several stages: the formation of the preparatory period (obtaining the breeding culture of phytoplankton and zooplankton, cultivation on different environments in order to establish an optimal scheme); obtaining of fish planting material and determination of fish objects for experiment; staging of the experiment (conducting research on feeding natural food of different processing of mother-crops). Scientific and experimental studies on the study of the functional state of the organism of hydrobionts when cultivated in the PAC with the use of an unconventional method of processing fodder mixed with their feeding give grounds to note the positive impact on its qualitative and functional characteristics. Investigation of the morpho-functional status of blood of freshwater fish on the background of the use of the proposed method for processing fodder mixed with fertilization in the early stages of ontogeny showed that stimulation of erythropoiesis, activation of protein metabolism in the organism of hydrobionts within the limits of the physiological norm occurs in the experimental group. The combination of several rapid methods (GRU) makes it possible to provide comprehensive research and acquires scientific and practical value, since the study of the physiological state of the object of biotesting against the background of the use of various factors involves the implementation of an entire chain of sequential research.

Key words: physiological and biochemical processes, hydrobionts, biologically active substances, nontraditional method of processing feed mixture.

\section{Функціональний стан організму прісноводних риб за умов впливу абіотичних чинників}

\author{
О.В. Гончарова ${ }^{1}$, Р.П. Параняк ${ }^{2}$, Б.В. Гутий ${ }^{2}$ \\ ${ }^{1}$ Дніпровський державний аграрно-економічний університет, м. Дніпро, Украӥна \\ ${ }^{2}$ Львівський національний Університет ветеринарної медиџини та біотехнологій імені С.3. Гжицького, \\ м. Львів, Україна
}

Мета роботи полягала у проведенні науково-експериментального аналізу вивчення функціонального стану організму гідробіонтів при вирощуванні у рециркуляційних аквакультуральних системах з використанням нетрадиційного методу обробки води, щзо 
була використана при формуванні кормосумімі для їх підгодівлі. Експериментальна частина роботи була проведена на базі лабораторії водних біоресурсів та аквакультури біотехнологічного факультету Дніпровського державного аграрно-економічного університету та Науково-експериментального иентру “Водні біоресурси та аквакультура Придніпров'я” Дніпровського державного аграрно-економічного університету. Практична частина роботи складалася з декількох етапів: формування підготовчого періоду (отримання маточної культури фітопланктону та зоопланктону, культивування на різних середовищах з метою встановлення оптимальної схеми); отримання рибопосадкового матеріалу та визначення об'єктів риб для експерименту; постановка експерименту (проведення дослідження з підгодівлі природним кормом різної обробки маточної культури). Науковоекспериментальні дослідження щуодо вивчення функціонального стану організму гідробіонтів при вирощування у РАС з використанням нетрадиційного методу обробки кормосуміші при їх підгодівлі дають підстави відмітити про позитивний вплив на ї̈ якісні та функиіональні характеристики. Дослідження морфо-функціонально стану крові прісноводних риб на тлі використання запропонованого методу обробки кормосуміші при підгодівлі на ранніх етапах онтогенезу показали, шзо в дослідній групі відбувається стимулячія еритропоезу, активачія білкового обміну в організмі гідробіонтів в межах фізіологічних величин. Поєднання декількох експрес-методів (ГРВ) робить можливим надання дослідженням комплексності та набуває науково-практичного значення, оскільки вивчення фізіологічного стану об'єкту біотестування на тлі використання різних чинників передбачає здійснення иілої ланки послідовних досліджень.

Ключові слова: фізіолого-біохімічні процеси, гідробіонти, біологічно активні речовини, нетрадиційний метод обробки кормосуміші

\section{Вступ}

Науково-експериментальні дослідження в індустріальній аквакультурі передбачають постійне удосконалення логічно-послідовних технологічних процесів щодо умов вирощування та підрощення гідробіонтів різних біологічно-господарських та вікових груп; умов годівлі, в тому числі й рецептів комбікормів, введення до їхнього складу біологічно активних речовин 3 різними функціональними характеристиками. Враховуючи шлях євроінтеграції в нашій країні в кожному секторі аграрного виробництва продукції тваринництва i рибництва, важливим аспектом $є$ впровадження новітніх біотехнологій, виключення гормональних препаратів, стимуляторів росту тощо (Paraniak \& Ostasha, 2014; Odynatska et al., 2017). Тому актуальним $є$ розробка та пошук оптимальних технологічних заходів, адаптованих під функціональний статус організму гідробіонтів за різних умов вирощування. Безумовно, 3 огляду фізіолого-біохімічного моніторингу, вивчення перебігу та рівня метаболічних процесів в організмі гідробіонтів на перший план виступають адаптаційно-компенсаторні механізми до певних промислових умов культивування, що своєю чергою, чинить вплив на формування потенціалу на ранніх стадіях онтогенезу, швидкість росту, морфометричну оцінку гідробіонтів тощо. Варто зауважити, що зазначені аспекти є важливими як для культивування гідробіонтів у РАС (рециркуляційних аквакультуральних системах), так і при зарибленні з метою поповнення іхтіофауни природних, штучних акваторій. При реалізації програм зариблення водойм маса тіла вже підрощеної молоді визначає кінцевий результат. Тому дослідження технологічних аспектів підгодівлі гідробіонтів, “екологічності” методів розведення риби, рівня забруднення водойм $є$ важливими складовими (Paraniak \& Ostasha, 2014).

Європейські стандарти вирощування гідробіонтів за різних форм, циклів (РАС, штучні та природні водойма) передбачають нормативні вимоги щодо “органічної продукції аквакультури”. Підтвердженням актуальності та практичної цінності таких досліджень $є$ власне професійне стажування автора статті у м. Basque, м. Toulouse (Франція, 2015-2018 рр.) (Honcharova \& Puhach, 2016; Honcharova et al., 2016; Kobets et al., 2017). Згідно з технологіями органічної аквакультури невеликі фермерські господарства, де вирощують риб 3 дотриманням вимог "bien-être", (добре доглянуті), AB (agriculture biologique - сільськогосподарська біологічна продукція) та ін., що своєю чергою передбачає використання повноцінних раціонів на основі біологічно активних та природних компонентів (Mykolenko et al., 2017; Honcharova \& Tushnytska, 2018). Зазвичай, така продукція у ринковій системі має вдвічі вищу цінову політику, оскільки характеризується відповідними якісними характеристиками. В цьому секторі більшість підприємців співпрацює 3 науковими установами, що здійснюють науковий супровід: модельні, камеральні дослідження, органолептичний аналіз рибної продукції, розробка біологічно-активних добавок для підгодівлі гідробіонтів. Прикладом є установа Institut national de la recherche agronomique (INRA, національний інститут сільськогосподарських досліджень, Франція), де вивчення фізіолого-біохімічних процесів $\epsilon$ одним із визначальних завдань при успішному веденні індустріальної аквакультури. Всі ці заходи є обгрунтованими та мають практичну цінність, оскільки можливість корегувати перебіг метаболічних процесів, поліпшувати адаптаційну можливість організму гідробіонтів корелює якісні та кількісні характеристики продукції аквакультури у майбутньому.

Отже, удосконалення та розробка новітніх методів поліпшення якісних характеристик готової біологічної продукції аквакультури набуває актуальності 3 кожним кроком євроінтеграції в Україні. Максимальне збереження поживних характеристик рибної продукції і дотримання всіх послідовних ланок технологічного процесу культивування гідробіонтів є одним 3 важливих завдань. Актуальним аспектом $є$ не лише культивування обраного об'єкту, а і попередня його обробка одним із доступних методів збагачення хімічного складу. При використанні фітопланктону в технологічній карті підгодівлі мальків, цьоголіток риб як додаткової добавки важливим $є$ той чинник, що вода $\epsilon$ основною складовою живих організмів. Серед відомих методів обробки води увагу привертає нетрадиційна обробка контактною нерівноважною низькотемпературною плазмою (Mykolenko et al., 2017). Попередня обробка води сприяє зміні ії характеристик взаємодії з окремими молекулами, ферментними комплексами на наноструктурному рівні. Однією із особ- 
ливостей води, підданої дії контактної нерівноважної плазми, є наявність у іiі складі активного кисню у формі пероксидних і надперекисних сполук, що забезпечує іiі антисептичні властивості. За умов культивування фітопланктону $з$ використанням нетрадиційного методу можна поліпшити функціональний стан організму гідробіонтів, що вживають такий корм 3 дотриманням вимог органічної аквакультури. В цьому плані тематика дослідження є обгрунтовано актуальною та набуває практичної цінності (Zolotarova \& Shniukova, 2008).

Мета дослідження полягала у проведенні науково-експериментального аналізу вивчення функціонального стану організму гідробіонтів при вирощуванні у РАС з використанням нетрадиційного методу обробки води, що була використана при формуванні кормосуміші для їх підгодівлі. Згідно з метою завдання були такі: вивчення впливу нетрадиційного методу обробки кормосуміші на пї якісні та функціональні характеристики; дослідження морфо-функціонально стану крові прісноводних риб на тлі використання запропонованого методу обробки кормосуміші при підгодівлі на ранніх етапах онтогенезу.

\section{Матеріал і методи досліджень}

Експериментальна частина роботи була проведена та продовжує виконуватися на базі лабораторії водних біоресурсів та аквакультури біотехнологічного факультету ДДАЕУ та Науково-експериментального центру "Водні біоресурси та аквакультура Придніпров'я” ДДАЕУ. Частина досліджень виконувалися за підтримкою державного гранту України для молодих вчених за держбюджетною темою ДДАЕУ “Розробка методів обробки сировини для ресурсозберігаючих технологій переробки с.-г. продукції та підвищення іiї продовольчої безпеки” (ДР № 0116U007412) та є науковою тематикою кафедри водних біоресурсів та аквакультури ДДАЕУ "Вивчення сучасного стану водойм Придніпров'я з метою визначення їх рибогосподарського використання" (2016- 2020 рр.). Практична частина роботи складалася 3 декількох етапів: формування підготовчого періоду (отримання маточної культури фітопланктону та зоопланктону, культивування на різних середовищах 3 метою встановлення оптимальної схеми); отримання рибопосадкового матеріалу та визначення об'єктів риб для експерименту; постановка експерименту (проведення дослідження 3 підгодівлі природним кормом різної обробки маточної культури). Функціональні характеристики фітопланктону та зоопланктону вивчали шляхом систематичного контролю згідно 3 діючими методами при постановці експериментальних досліджень.

Обробка води контактною нерівноважною плазмою проводилася у лабораторії плазмохімічних технологій ДВНЗ "Український державний хімікотехнологічний університет" на лабораторній установці (Pivovarov et al., 2017). Під час тестування фітопланктону вивчали рівень розвитку, пігментацію та біомасу, використовували мікропопуляції альгологічно чистої культури зеленої прісноводної водорості
Chlorella vulgaris Beij, Riccia fluitans, Spirulina (Arthrospira) platensis, Lémna mínor L. Попередній період передбачав біотестування,вивчали зміну рівня життєдіяльності інфузорій (Paramecium caudatum), артемії (Artemia salina). Середня температура становила в резервуарах $22-25^{\circ} \mathrm{C}$, використовували освітлення лампами денного світла (інтенсивність 2500 лк) 3 автоматичною регуляцією впродовж 16 год на добу. В експериментальних умовах в культуральне середовище водоростей додавали оброблену воду в оптимальному співвідношенні, встановленому раніше (Honcharova \& Tushnytska, 2018). Вміст пігментів визначали спектрофотометрично. Клінічний огляд риби проводили систематично. Відбір проб для визначення гематологічних показників здійснили впродовж експерименту, у крові риб визначали основні морфо-функціональні показники згідно загальноприйнятих методів. Об'єкти для дослідження були різні (вивчали фізіологічний стан організму, показники швидкості розвитку та метаболічні процеси коропа (C. carpio), тиляпії (O. Mossambicus), мармурового кларієвого сома (Clarias gariepinus). Кожний з видів прісноводних риб утримували по 30-40 екземплярів в кожному акваріумі, з температурою води $22-26{ }^{\circ} \mathrm{C}$, активністю іонів водню 7,2-7,4 одиниць, вміст розчиненного кисню в середньому становив 6,1-6,9 мг/л. Окрім того, були здійснені експедиційні виїзди, пошук доступної літератури, зважування та морфометрична оцінка гідробіонтів, основні результати були використанні при оформленні патентів на корисну модель. Частина матеріалу експериментального характеру була виконана впродовж декількох стажувань та проведення науково-дослідницької роботи (відповідно до меморандуму про співпрацю з французькими колегами) на органічних рибних фермерських господарствах, науково-дослідницьких інститутах, що мають лабораторії (INRA), Франція м. Тулуза, Бретань, Баскі, Рошель. На базі Lycée Agricole Saint Christophe, Société TERHYDRO à Latrape (France) Ta Institut national de la recherche agronomique. Аналіз величин пластичних ознак гідробіонтів виконано за системою абсолютних значень. Результати оброблені статистично за допомогою програми Microsoft Excel $(\mathrm{M} \pm \mathrm{m})$.

\section{Результати та їх обговорення}

Попередня обробка води контактною нерівноважною плазмою та культивування маточної культури фітопланктону на базі такого середовища сприяла стимулюванню “енергетичної ланки” катаболічних процесів Spirulina (Arthrospira) platensis + Lémna + Chlorella vulgaris Beij, Riccia fluitans. Про позитивні зміни вказаних модельних об'єктів біотехнології свідчить і рівень пігментації, і динаміка розвитку біомаси в дослідній групі. Використання первинної сировини 3 вивчаємих водоростей надало можливість провести порівняльну характеристику фізіологічного стану організму гідробіонтів, яким вводили до ЗГР кормосуміш у встановленій раніше пропорції. Фрагмент здійснення аналізу функціональних характеристик фітопланктону показано на рис. 1. 


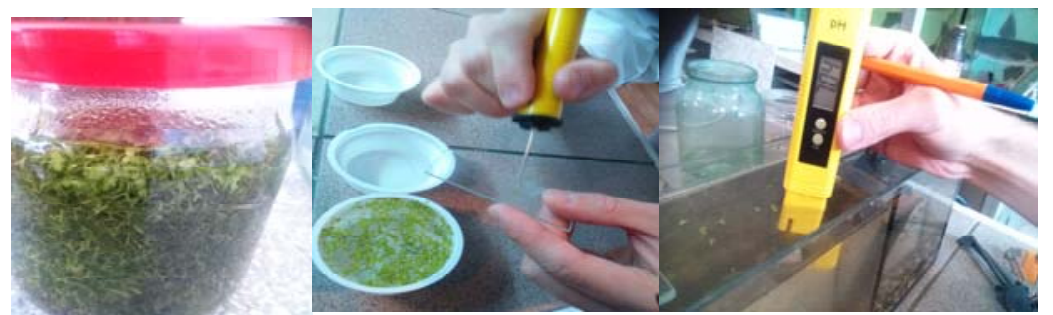

Рис. 1. Фрагмент вивчення якісних та кількісних характеристик фітопланктону для підгодівлі гідробіонтів

Результати проведення попереднього періоду щодо аналізу токсичності показали, що в дослідній групі 1 , де зоопланктон для розвитку використовував воду, підданої дії контактної нерівноважної плазми протягом 10 хв, тестована речовина відповідала класу “нетоксична”. Аналогічно для дослідної групи організмів, що виступали тест-об'єктами для плазмохімічно активованої води 3 концентрацією пероксидних сполук 500 мг/л, цей показник був вищим 3 відповідністю класу “нетоксичний” (рис. 2).

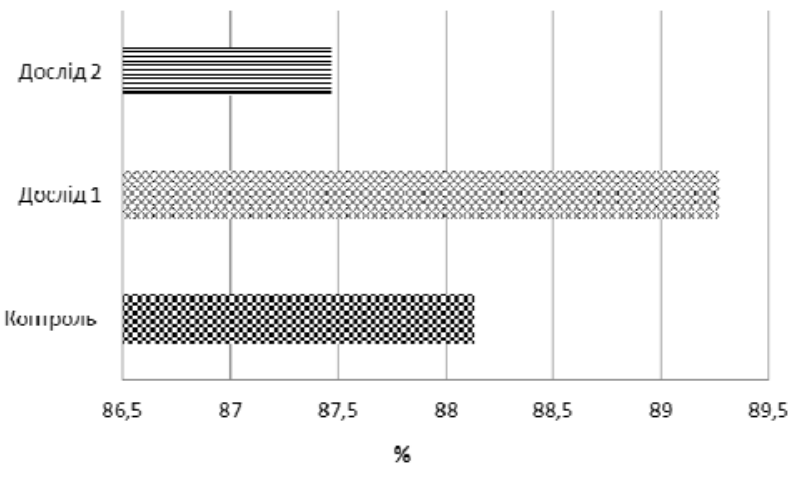

Рис. 2. Вивчення показника токсичності (тест-об'єкт Paramecium caudatum)

При використанні води, обробленої запропонованим методом як середовища для культивування враховували, що дані біологічні об'єкти надмірно сенсорні до змін водного середовища, що відображалось на рівні активності поглинання доступних речовини проти градієнту концентрації. Так, ми допускаємо, що в тому числі завдяки таким властивостям мікроводорості накопичували речовини в кількостях, які в декілька разів перевищували їх вміст у воді. Результати наступного експериментального дослідження щодо використання як експрес-методу попередньої оцінки функціонального статусу об’єктів 3 використанням методу газорозрядної візуалізації показали, що цей спосіб надає можливість попередньо оцінити ефективність використання кормового чинника без комплексного лабораторного дослідження з залученням спеціалізованого обладнання. Так, вивчення біопотенціалу плазмохімічно активованої води газовий розряд, що виникав під час візуалізаційного аналізу проби, чинив вплив на стан об'єкту дослідження, викликаючи вторинні емісійні і теплові процеси. Аналіз спектру випромінювання надав можливість обрати параметри: ентропія і площа випромінювання у двох проекціях. Показники правої і лівої проекції контрольного і дослідного зразків показали вірогідну різницю між собою у випадку аналізу зразка води, підданої обробці (рис. 3).

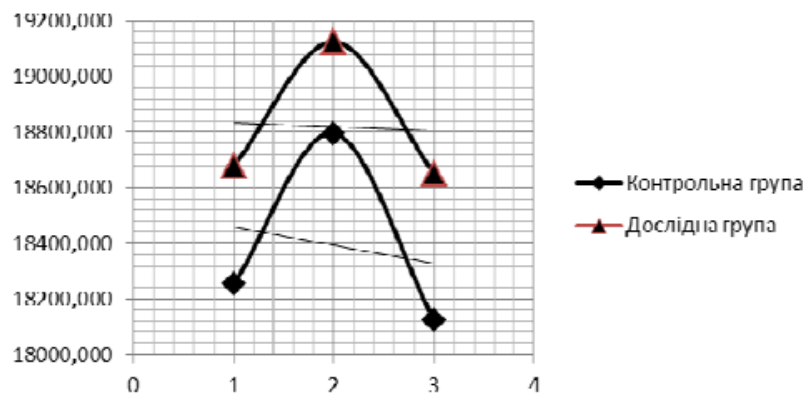

Рис. 3. Аналіз показників фіксації біопотенциалу середовища для культивування фітопланктону (результат ГРВ-зйомки тест-об'єктів)

За допомогою програмного забезпечення “GDV Capture" було зафіксовано інтенсивність випромінювання на ГРВ-грамі: форма “корони світіння” та іiі площа після обробки води, контактною нерівноважною плазмою зменшувалася (Korotkov, 2007; Korotkov et al., 2010; Korotkov \& Yakovleva, 2014). У дослідній групі 2 крапля води характеризувалась вищими променями випромінювання та мала більш широкий спектр. Тому надалі використовували воду з дослідної групи 2. Зауважимо, що на підставі отриманих даних ГРВ-грам тест-об'єктів, в тому числі й краплі крові гідробіонтів з усіх експериментальних та контрольних груп, були зроблені експериментальні дослідження складу крові в лабораторних умовах. Результати ГРВметоду і лабораторного підтвердилися результатами наведеними далі в статті. Після інтерпретації параметрів в цифрові показники по лівій проекції (площа світіння), фронтальній проекції і правої проекції можна зробити висновок про вищий біопотенціал тестоб'єктів, які культивувалися на обробленій плазмохімічно активованій плазмі.

Еритроцитарна картина циркулюючої крові $є$ достатньо інформативним дослідженням, оскільки вона відображає перебіг адаптаційно-компенсаторних реакцій, регенеративних та дегенеративних процесів у крові та кровотворних органах. Результати дослідження гематологічного складу крові цьоголіток коропа показали, що в дослідній групі загальна кількість еритроцитів та вміст гемоглобіну перевищувала значення в контролі на 9 та $12 \%$ відповідно.

При дослідженні основних морфо-функціональних показників крові цьоголіток була виявлена залежність між живою масою та еритроцитарним складом крові, тобто, чим більша маса (в дослідній групі), тим біль- 
ша загальна кількість еритроцитів, i, навпаки, менша маса тіла призводить до їх зменшення.

\section{Таблиця 1}

Морфо-функціональні показники крові українського лускатого коропа за умов впливу абіотичних чинників $(\mathrm{M} \pm \mathrm{m}, \mathrm{n}=6)$

\begin{tabular}{lrc}
\hline \multicolumn{1}{c}{ Показники } & Контроль & \multicolumn{1}{c}{ Дослід } \\
\hline Еритроцити, Т/л & $1,15 \pm 0,02$ & $1,26 \pm 0,01^{* *}$ \\
Гемоглобін, г/л & $107,79 \pm 2,61$ & $120,1 \pm 2,34^{* *}$ \\
Гематокрит,\% & $24,15 \pm 1,28$ & $29,07 \pm 0,95^{*}$ \\
$\mathrm{MCH}$, пг & $94,35 \pm 3,46$ & $95,67 \pm 1,76$ \\
$\mathrm{MCHC}, \%$ & $45,05 \pm 1,99$ & $41,58 \pm 2,00$ \\
$\mathrm{MCV}$, мкм $^{3}$ & $211,54 \pm 14,24$ & $231,73 \pm 8,63$ \\
\hline Примітка: ${ }^{*}-\mathrm{P}<0,05 ;{ }^{* *}-\mathrm{P}<0,01$ порівіняно з показника- \\
ми контрольної групи
\end{tabular}

Гематокритний показник відображає загальний стан гомеостазу організму цьоголіток коропа, вищий рівень гематокриту в дослідній групі пов'язаній 3 більшою кількістю еритроцитів в їх крові. Гемоглобін $\epsilon$ основною білковою частиною у крові, провідна функція якої полягає у постачанні кисню до тканин, органів та у видаленні вуглекислого газу. Тому визначення вмісту гемоглобіну в крові є одним із важливих показників загального функціонального стану їх організму. Як відомо, ступінь насиченості еритроцитів гемоглобіном характеризує середній вміст гемоглобіну в еритроциті. Мікрокорпускулярні індекси в крові коропів дослідної групи були вищими за значення в контрольній групі: вміст гемоглобіну в еритроциті $(\mathrm{MCH})-5,3 \%$, середній об'єм еритроцитів (MCV) на 4\%, середня концентрація гемоглобіну в еритроциті (МСНС) - 3,8\%. Ймовірно, вказані значення індексів еритроцитів мають кореляційний зв'язок із загальною кількістю еритроцитів та концентрацією гемоглобіну.

Одним із важливих показників стану обміну речовин в організмі є білковий склад крові. Залежно від інтенсивності обміну білків може змінюватися вміст загального білка та його фракцій у сироватці крові. Результати наших досліджень основних показників білкового обміну показали, що вміст загального білка був вищим в крові коропа, якому вводили додатково до ЗГР (загальногосподарського раціону) оброблену кормосуміш. Різниця становила $12,1 \%$. Білковий коефіцієнт відображає співвідношення альбумінової i глобулінової фракцій крові, в дослідній групі він становив 1,38, що на 23\% було вищим порівняно 3 контрольною групою. Більший рівень альбумінів може свідчить, що в їх організмі більш активно відбувається білково-синтезуючі процеси. Крім того, при дослідженні кормового коефіцієнту було встановлено, що в дослідній групі він був меншим за контрольні значення, що дає можливість дискутувати про більш активний перебіг метаболічних процесів, отже, і засвоєння поживних речовин коропом в дослідній групі.

Отже, культивування фітопланктону, з якого формували кормосуміш, сприяло активації метаболічних процесів в організмі дослідної групи. Щоденне вживання цьоголітками коропа обробленої кормосуміші позначилося на загальному функціональному статусі їх організму, процесах окиснення та кисневої ємності крові.

Найменші витрати корму при вирощуванні тиляпії були у дослідній групі, яка вирощувалась на раціоні 3 вмістом протеїну $40 \%+$ Spirulina (Arthrospira) platensis + Lémna + Chlorella vulgaris Beij, Riccia fluitans. Вивчення впливу умов годівлі на швидкість росту тиляпії дозволило проаналізувати також позитивну динаміку. Дослідження показали, що найвищий приріст маси тіла та найменші витрати корму, виживання коропа були у дослідній групі.

\section{Таблиця 2}

Результати вивчення впливу кормового чинника на масу тіла тиляпії ( $\mathrm{M} \pm \mathrm{m}, \mathrm{n}=30)$

\begin{tabular}{lcc}
\hline \multicolumn{1}{c}{ Показники } & $\begin{array}{c}\text { контрольна } \\
\text { ЗГР з вмістом } \\
\text { протеїну } 30 \%\end{array}$ & $\begin{array}{c}\text { дослідна } \\
\text { вміст протеїну } \\
40 \%+\text { оброблена } \\
\text { кормосуміш }\end{array}$ \\
\hline $\begin{array}{l}\text { Початкова маса, г } \\
\text { Кінцева маса }\end{array}$ & 12,9 & 12,9 \\
60-добової тиляпії, г & $71,9 \pm 1,4$ & $85,2 \pm 1,1$ \\
Вихід молоді, \% & 92,1 & 96,9 \\
\hline
\end{tabular}

\section{Таблиця 3}

Результати вивчення впливу кормового чинника на морфо-функціональні показники крові тиляпії (M $\pm \mathrm{m}$, $\mathrm{n}=6$ )

\begin{tabular}{lcr}
\hline \multicolumn{1}{c}{ Параметри } & \multicolumn{1}{c}{ Контрольна } & \multicolumn{1}{c}{ Дослідна } \\
\hline Кількість еритроцитів, Т/л & $1,3 \pm 0,10$ & $1,5 \pm 0,09$ \\
Вміст гемоглобіну, г/л & $51 \pm 2,92$ & $62 \pm 2,35$ \\
Гематокрит, \% & $40,8 \pm 1,89$ & $41,0 \pm 1,91$ \\
Загальний білок, г/л & $42,3 \pm 1,12$ & $43,1 \pm 0,85$ \\
\hline
\end{tabular}

\section{Таблиця 4}

Результати вивчення впливу кормового чинника на морфо-функціональні показники крові мармурового coмy, $(\mathrm{M} \pm \mathrm{m}, \mathrm{n}=6)$

\begin{tabular}{lcc}
\hline \multicolumn{1}{c}{ Параметри } & Контрольна & Дослідна \\
\hline Кількість еритроцитів, Т/л & $1,6 \pm 0,21$ & $1,9 \pm 0,30^{*}$ \\
Вміст гемоглобіну, г/л & $89 \pm 1,35$ & $92 \pm 1,10$ \\
Гематокрит, \% & $46 \pm 0,38$ & $48 \pm 0,78$ \\
Загальний білок, г/л & $31,2 \pm 1,40$ & $33,5 \pm 1,20^{*}$ \\
\hline
\end{tabular}

Примітка: ${ }^{*}-\mathrm{P}<0,05 ;{ }^{* *}-\mathrm{P}<0,01$ порівіняно 3 показниками контрольної групи

Отже, проведені експериментальні дослідження щодо морфо-функціональних показників крові молоді тиляпії надали можливість зробити висновок про позитивний вплив кормової добавки на фізіологічний стан організму риб, більш активні катаболічні процеси та вищу резистентність організму дослідної риби.

\section{Висновки}

Науково-експериментальні дослідження щодо вивчення функціонального стану організму гідробіонтів при вирощування у РАС 3 використанням нетрадиційного методу обробки кормосуміші при їх підгодів- 
лі дають підстави твердити про позитивний вплив на iii якісні та функціональні характеристики. Дослідження морфо-функціонального стану крові прісноводних риб на тлі використання запропонованого методу обробки кормосуміші при підгодівлі на ранніх етапах онтогенезу показали, що в дослідній групі відбувається стимуляція еритропоезу, активація білкового обміну в організмі гідробіонтів в межах фізіологічної норми. Поєднання декількох експрес-методів (грв) робить можливим надання дослідженням комплексності та набуває науково-практичного значення, оскільки вивчення фізіологічного стану об'єкту біотестування на тлі використання різних чинників передбачає здійснення цілої ланки послідовних досліджень.

Перспективи подальших досліджень будуть спрямовані на вивчення оксидативного статусу клітин фітопланктону, концентрації хлорофілу та амінокислотного складу за умов культивування на воді, обробленої нетрадиційним методом. Актуальним буде дослідження хімічного складу філе та вивчення зразків кишківника гідробіонтів, яким додатково вводили кормосуміш, оброблену нетрадиційним методом.

\section{References}

Honcharova, O.V., \& Puhach, A.M. (2016). Harmonizatsiia ta biotekhnolohichne onovlennia metodiv determinizatsii yakosti biolohichnoi produktsii. Young Scientist, 9(36), 111-114. http://molodyvcheny.in.ua/files/journal/2016/9/68.pdf (in Ukrainian).

Honcharova, O.V., \& Tushnytska, N.I. (2018). Fiziolohichne obhruntuvannia vykorystannia netradytsiinoho metodu obrobky syrovyny $\mathrm{v}$ akvakulturi. Rybohospodarska nauka Ukrainy, 1, 5464 (in Ukrainian).

Honcharova, O.V., Astre, P., \& Astre, M. (2016). Perspektyvy rozvytku akvakultury v Ukraini z ohliadu yevropeiskoho dosvidu. Naukovyi zhurnal "Borysten", 04(297), 24-26 (in Ukrainian).

Hrytsyniak, I.I., \& Tretiak, O.M. (2018). Deiaki rezultaty ostannikh doslidzhen Instytutu rybnoho hospodarstva. Zbirnyk materialiv I-yi Mizhnarodnoi naukovopraktychnoi konferentsii "Suchasni problemy ratsionalnoho vykorystannia vodnykh bioresursiv", $\mathrm{m}$. Kyiv 15-17 travnia 2018 r.: Kyiv: Pro format, 8-12 (in Ukrainian).

Kobets, A.S., Honcharova, O.V., \& Puhach, A.M. (2016). Sposib vyznachennia zhyvykh zarodkiv u period inkubatsii yaiets. Pat. No. 111577 UA; podana zaiavka: 03.06.2016; opublikovano: 10.11.2016, Biuleten No. 21 (in Ukrainian).
Kobets, A.S., Honcharova, O.V., \& Puhach, A.M. (2017). Prystrii retsyrkuliatsiinoho vodopostachannia dlia otrymannia orhanich-noi produktsii $\mathrm{v}$ akvakulturi. Patent Ukrainy № 120644. Data podannia zaiavky: 31.05.2017. Publikatsiia vidomostei pro vydachu patentu: 10.11.2017, Biul. № 21 . http://uapatents.com/4-120644-pristrijjrecirkulyacijjnogo-vodopostachannya-dlyaotrimannya-organichno-produkci-v-akvakulturi.html (in Ukrainian).

Korotkov, K.G. (2007). Princip anali za GRV v biojelektrografii. Sankt-Peterburg: Renome (in Russian).

Korotkov, K.G., \& Yakovleva, K.G. (2014). Primenenie metoda GRV - biojelektrografii v medicine (obzor literatury). Vestnik Sankt-Peterburgskogo universiteta, 2, 175-187 (in Russian).

Korotkov, K.G., Matravers, P., Orlov, D.V., Williams, B.O. (2010). Application of Electrophoton Capture (EPC) Analysis Based on Gas Discharge Visualization (GDV) Technique in Medicine: A Systematic Review. The Journal of Alternative and Complementary Medicine, 16(1), 13-25. doi: 10.1089/acm.2008.0285.

Mykolenko, S.Iu., Honcharova, O.V., \& Puhach, A.M. (2017). Innovatsiini metody obrobky prodovolchoi syrovyny. Dnipro: Zhurfond (in Ukrainian).

Odynatska, H.V., Paraniak, R.P., Chemerys, V.A., \& Petruniv, V.V. (2017). Features of environmental innovations in the Lviv region. Scientific Messenger LNUVMB, 19(79), 178-182. https://nvlvet.com.ua/ index.php/agriculture/article/view/2804.

Paraniak, R.P., \& Ostasha, T.P. (2014). Okremi aspekty ekolohichnoho ryzyku antropohennoho zabrudnennia malykh richok Lvivskoi oblasti. Naukovyi visnyk Lvivskoho natsionalnoho universytetu veterynarnoi medytsyny ta biotekh-nolohii im. Gzhytskoho, 16, 2(3), 318-326 (in Ukrainian).

Pivovarov, A., Mykolenko, S., \& Honcharova, O. (2017). Biotesting of plasma-chemically activated water with the use of hydrobionts. Eastern-European Journal of Enterprise Technologies, 4, 10(88), 44-50. doi: 10.15587/1729-4061.2017.107201.

Vergolyas, M.R., \& Goncharuk, V.V. (2016). Toxic effects of heavy metals on the hydrobionts' organism. Journal of Education, Health and Sport, 6(6), 436444. doi: 10.5281/zenodo.56065.

Zheltov, YuO. (2003). Metodychni vkazivky z provedennia doslidiv po hodivli ryb. Rybne hospodarstvo, 62, 23-28 (in Ukrainian).

Zolotarova, O.K., \& Shniukova, Ye.I. (2008). Perspektyvy vykorystannia mikrovodorostei u biotekhnolohii. Kyiv: Alterpres (in Ukrainian). 